\title{
Patterns of community and species diversity in grassland vegetation of the southwestern Iberian System (Spain)
}

\author{
M. Pilar Rodríguez-Rojo, Santiago Sardinero \& Federico Fernández-González
}

\begin{abstract}
Rodríguez-Rojo, M.P., Sardinero, S . \& Fernández-González, F. Patterns of community and species diversity in grassland vegetation of the southwestern Iberian System (Spain). Lazaroa 34: 219-236 (2013).

This paper reports a floristic and phytocenologic review of the mesic and dry grasslands of the southwestern Iberian Mountain System (Spain) based on numerical and indicator species analysis. The crispness of classification was checked resulting in four main groups that classify grasslands in mesic (Molinio-Arrhenatheretea and Nardetea), semi-dry calcareous (Festuco-Brometea), dry calcareous (Sideritido fontquerianae-Arenarion microphyllae), and dry siliceous grasslands (Hieracio castellani-Plantaginion radicatae). DCA and CCA were performed on topographic parameters as explanatory variables of the community diversity and differences in variability between communities were also tested with ANOVA. Rock cover and slope best explained the differences in the floristic composition between the main vegetation groups, and for the discrimination of the dry cryoturbated grasslands (Sideritido-Arenarion) from other types of grasslands, while altitude best discriminated some associations belonging to the same main vegetation group, such as the semi-dry grasslands (Cirsio microcephalae-Onobrychidetum hispanicae and Festuco andresmolinae-Brachypodietum phoenicoidis) and dry grasslands of upfrozen soils (Festucetum hystricis and Paronychio capitatae-Artemisietum assoanae). The exploration of the diagnostic species in combination with the topographic patterns of the community diversity brought out the phytosociological interpretation of transitional communities, like the case of Festucetum hystricis variant semi-dry with Plantago maritima subsp. serpentina.
\end{abstract}

Keywords: Classification, Canonical Correspondence Analysis (CCA), Detrended Correspondence Analysis (DCA), Pastures, Species richness, Topography.

Resumen: Rodríguez-Rojo, M.P., Sardinero, S. \& Fernández-González, F. Patrones de diversidad fitocenótica y florística en los pastizales del Sistema Ibérico suroccidental. Lazaroa 34: 219-236 (2013).

Se ha realizado una revisión florística y fitocenológica de los pastizales mesófilos y xerófilos del Sistema Ibérico suroccidental, basada en análisis numéricos y de especies diagnósticas. La mayor nitidez de la clasificación se obtiene con cuatro grandes grupos que clasifican los pastizales en mésicos (Molinio-Arrhenatheretea y Nardetea), calcícolas semi-xerofíticos (Festuco-Brometea), calcícolas xerofíticos (Sideritido fontquerianae-Arenarion microphyllae) y silicícolas xerofíticos (Hieracio castellani-Plantaginion radicatae). Las variables topográficas se incluyeron en las ordenaciones (DCA y CCA) como posibles variables explicativas de la composición florística, y las diferencias topográficas entre grupos se analizaron mediante ANOVA. La cobertura de rocas y la pendiente han resultado ser las variables que mejor explican las diferencias en la composición florística entre los cuatro grandes grupos y para la discriminación de los pastizales xerofíticos crioturbados (Sideritido-Arenarion), mientras que la altitud se interpretó como un factor discriminante entre algunas asociaciones, como los prados meso-xerofíticos (Cirsio microcephalae-Onobrychidetum hispanicae y Festuco andresmolinaeBrachypodietum phoenicoidis) y los pastizales secos crioturbados (Festucetum hystricis y Paronychio capitatae-Artemisietum assoanae). El análisis de especies diagnósticas en combinación con los patrones topográficos de diversidad fitocenótica sirvieron para la interpretación fitosociológica de comunidades transicionales, como es el caso de la variante de ambiente semiseco de Festucetum hystricis con Plantago maritima subsp. serpentina.

Palabras clave: Clasificación, Análisis de Correspondencia Canónica (CCA), Análisis de Correspondencia sin tendencias (DCA), Pastos, Riqueza florística, Topografía.

\footnotetext{
* Departamento de Ciencias Ambientales. Instituto de Ciencias Ambientales. Universidad de Castilla-La Mancha. Avda. Carlos
} III s/n. E-45071 Toledo, Spain. E-mail: MPilar.Rodriguez@uclm.es. 


\section{INTRODUCTION}

Plant diversity patterns in grasslands have been for a long time a question of attention for management and conservation purposes. Several studies have dealt with the soil $\mathrm{pH}$, altitude, topography (aspect and slope), and grazing intensity, as the main local abiotic factors influencing the variation of the plant species composition and species richness (CRICHTLEY \& al., 2002; AMEZAGA \& al., 2004; BENNIE \& al., 2006; KLIMEK \& al., 2007; MARINI \& al., 2007; JIMÉNEZ-ALFARO \& al., 2013). Topography has a strong effect on local hydrology and additionally affects patterns in local temperature and irradiation, as well as, local exposure to wind (MOESLUND \& al., 2013); thus, it is considered an indirect factor for shaping local grassland vegetation patterns. Mechanisms controlling plant species richness in grasslands in Europe have been explained by the positive effect of slope angle (MAURER \& al., 2006; KLIMEK \& $a l ., 2007$; MARINI \& al., 2007), and the negative effect of soil acidification and altitude (PIQUERAY \& al., 2007; KOPÉC \& al., 2010). Over the worldwide, the soil $\mathrm{pH}$ pattern may be different across floristic regions because the direction of the relationship between richness and $\mathrm{pH}$ depends on whether the species pool has its evolutionary origin on soils of high or low pH (PÄRTEL, 2002). In Europe, it may be also considered that the higher contemporary calciphile to acidiphile richness ratio corresponds to a disproportionate decline of acidic habitats and their flora during the ice age times (EWALD, 2003), which would also explain that the majority of the central European flora is restricted to base rich, calcareous soils.

The diversity of grasslands in the southwestern Iberian Mountain System s.l. has been reported in some traditional phytosociological studies (LÓPEZ GONZÁLEZ, 1978; BARRERA, 1985; RODRÍGUEZ-RoJo \& al., 2010, 2011, 2012). They pointed out important levels of community diversity and originality in this territory, as a consequence of a varied lithology, including calcareous and siliceous substrates (limestone, dolomites, slates, quartzites, red sandstones, albian sands, etc), combined with a complex relief that also appear in near mountains (RIVAS GODAY \& BORJA, 1961;
GAVILÁN \& al., 2012). Some mesic and dry grasslands are included in the Catalogue of Habitats of Special Protection in Castilla-La Mancha (Nature Conservation Law 9/1999) or in the Annex I of Habitats Directive (92/43/EC): semi-dry calcareous grasslands (Festuco-Brometea), Nardus stricta swards (species-rich Nardus grasslands), cryoturbated calcareous grasslands (alpine and subalpine calcareous grasslands). The cryoturbated calcareous grasslands colonize the ridges and slopes of the highlands, mesic grasslands fill the valley bottoms and basins, while semi-dry grasslands occupy a transitional range among both extremes but their topographic affinity has not been properly defined (RODRÍGUEZ-ROJo \& al., 2010).

Because of the varied lithology combined with the complexity of relief given in this territory, and under the current moderate grazing intensity and no mowing practices, we hypothesize that the main floristic gradients in the mesic and dry grasslands should be related to lithological and topographic factors, and that these can serve as good predictors of species composition. According to this, our study develops an application of numerical and indicator species analyses on dry and mesic grasslands in the southwestern Iberian System in order to give responses to the following issues: (1) to determine the main vegetation types of these grasslands, (2) to compare the resulting classification with that used traditionally by previous authors, (3) to determine the diagnostic species of each vegetation type, and (4) to assess how far topographical (slope, aspect, rock cover and altitude) and lithological factors may discriminate the community diversity and the patterns of species richness in these grasslands.

\section{MATERIAL AND METHODS}

\section{STUDY AREA}

The main rangelands prospected were Sierra de Albarracín, Sierra de Valdemeca and Serranía de Cuenca, which according to the geomorphological sectorization of GuTIÉRREZ \& PEÑa (1994) belong to the central sector and southwestern area of the Iberian System (Cordillera Ibérica) (Figure 1). The 


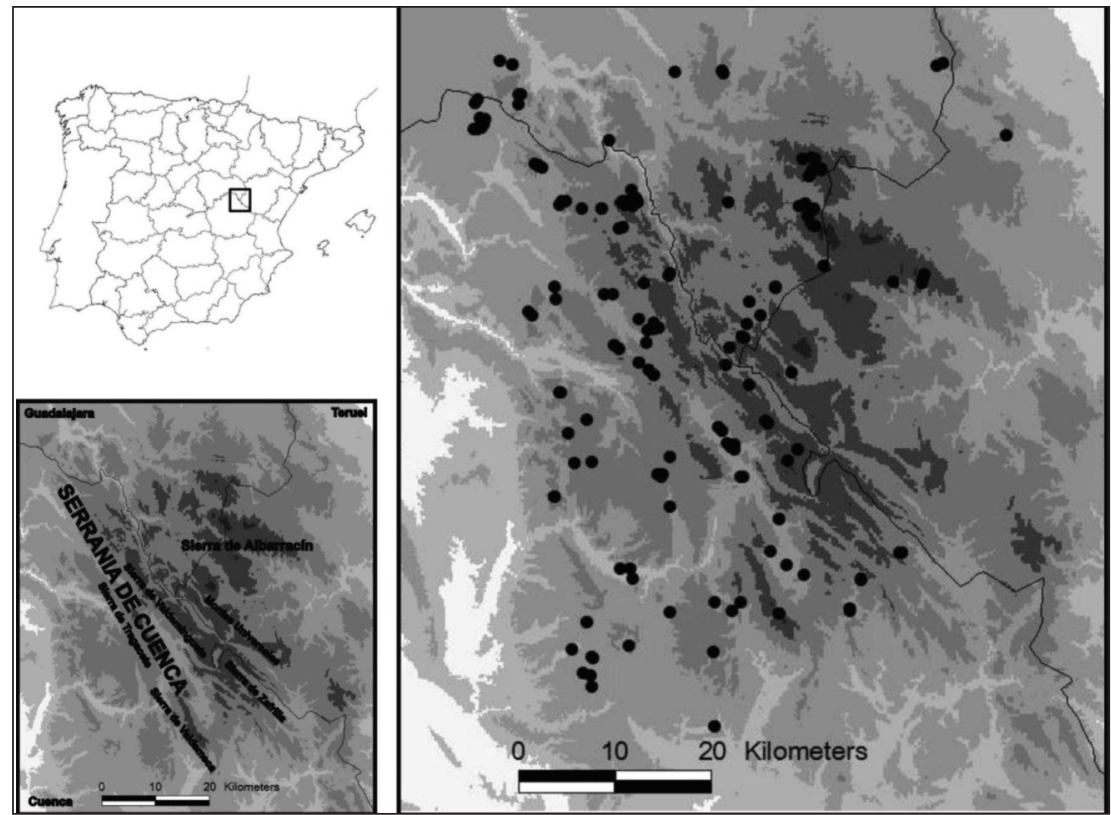

Figure 1. - Location of the study area and distribution of the sampled relevés.

highest altitude is registered in Caimodorro peak (1920 m asl). According to the bioclimatic typology of RIVAS-MARTíNEZ (2007), the territory is in the transition between the macrobioclimates Mediterranean, in the lowlands, and Temperate (submediterranean variant) in the uplands (Figure 2). The bioclimatic belts of the study area correspond to the upper supramediterranean, upper suprasubmediterranean and lower orosubmediterranean, with ombrotypes ranging from upper subhumid to upper humid. Biogeographically, the territory is framed into the Maestracensean and Celtiberian-
Alcarrean sectors, Mediterranean Central Iberian province (RIVAS-MARTíNEZ, 2007).

\section{DATA SAMPLING}

Field sampling was carried out from 2009 to 2012 during summer (mid-June to late-July). We used orthoimages, forestry maps, topographic maps and geologic maps to locate a network of grassland areas of a certain extension that were also representative of the whole territory in terms of the geological and altitudinal variation. The

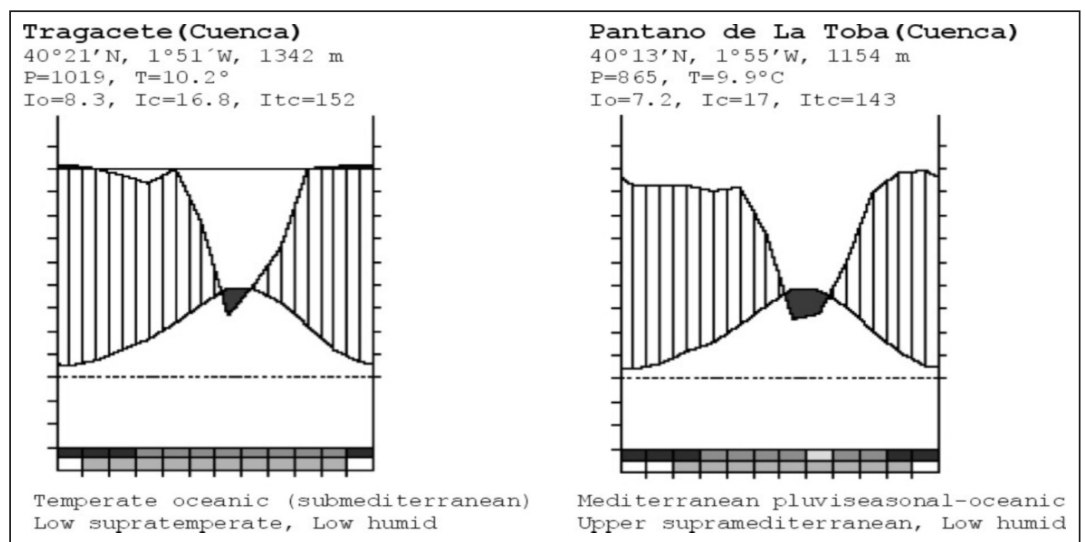

Figure 2. - Climatic diagrams in the southwestern Iberian System (RIVAS-MARTínEZ, 2007). 
distribution of the sampled sites in the selected areas was designed to cover the lithological, topographical and altitudinal variation in every one of them. Most of the areas were located in the Serranía de Cuenca and Alto Tajo (Cuenca and Guadalajara provinces), while Sierra de Albarracín (Teruel) was prospected in order to complete the representation of siliceous grasslands (Figure 1). Plot size was fixed as a rule in 10x10 m2. Plant cover indices were visually estimated in percentage values $(0.1,1,5,10,20,30,40,50,60,70$, 80,90 and $100 \%$ ). Altitude, slope, exposure, rock cover and bare soil cover percentages were recorded in each plot, as well as, other supplementary data (total plant cover, livestock type, grazing system, etc.). Taxonomic nomenclature follows the proposals of Flora iberica (CASTROVIEJO \& al., 1986-2012) except for Compositae and Poaceae taxa that follow the Euro+Med PlantBase (Euro+Med, 2006-2013 ww2.bgbm.org/EuroPlusMed/ [accessed 4-4-2013]).

\section{NuMERICAL ANALYSES}

Several types of agglomerative and divisive classification were applied to the final dataset of 160 relevés and 408 species, including the beta-flexible linkage method (beta $=-0.25$ ) with Sorensen distance, Ward's method with relative Euclidean, and TWINSPAN modified according to ROLEČEK \& al. (2009) with three pseudo-species cut-off levels $(0 \%, 5 \%$ and $25 \%)$ and total inertia as a heterogeneity measure. Percentage cover values were logtransformed in order to reduce the importance of dominant species (VAN DER MAAREL, 1979), excepting for the application of TWINSPAN algorithm that uses pseudo-species cut-off levels. After examining several partitions of the data set, we selected the partition with beta-flexible clustering that produced the less-chained dendrogram and more homogeneous clusters with respect to the ordination (DCA) of the same dataset. The number of clusters accepted corresponds to the alliances traditionally recognized in the literature. Nevertheless, the crispness of classification was checked using the method suggested by BotTA-DuKÁt \& al. (2005) that revealed that crispness is higher at the level of four clusters and decreases gradually when the number of clusters increased. Centroids of each cluster were calculated using the Euclidean distance and 5 relevés were reassigned according to their relationship to the nearest cluster centroid. The cluster membership of these 5 relevés was also checked in the DCA scatter plot.

For the calculation of diagnostic species values, the size of the clusters was standardized to equal size of $15 \%$ of the data set (TiCHÝ \& CHYTRÝ, 2006). We only show the diagnostic species with values of the $\Phi$-coefficient of association $\geq 0.25$ for at least one cluster and with a statistically significant affinity at the probability level $<0.001$ according to Fisher's exact test.

Using canonical correspondence analysis (CCA), the relationships between altitude, south exposure, west exposure, slope, rock cover and altitude with species composition of the vegetation data were tested. Previously, all these environmental variables were passively projected onto the DCA diagram. The power of each explanatory variable was also tested with a Monte Carlo permutation test (reduced model, 999 permutations) and a forward manual selection procedure was used to select the most important variables. Differences in altitude among particular vegetation types were tested with the Tukey post-hoc test following oneway ANOVA, while differences in slope and rock cover were tested with Kruskal-Wallis ANOVA by Ranks applied for variables with a non-gaussian distribution. An attribute plot showing changes in species richness along the first two DCA axes was constructed applying a Generalized Additive Model (GAM), using Poisson distribution and testing for nonlinearity.

Numerical analyses were performed with JUICE 7.0 software (TICHÝ, 2002) combined with PC-ORD v.5 (MCCUNE \& MEFFORD, 1999) for Cluster Analysis, and CANOCO 4.5 package (TER BRAAK \& ŠMILAUER, 2002) for DCA and CCA.

\section{RESULTS}

\section{VEGETATION CLASSIFICATION AND PATTERNS}

Ten clusters were considered in the dendrogram that best fit with the classification of the re- 




Figure 3. - Dendrogram of the flexible beta clustering $(\beta=-0.25)$. The numbers of clusters correspond to the synoptic table.

levés at the association level (Figure 3). However, maximum crispness occurred at the cutting level of the following four groups: A) mesic grasslands (clusters 1-4), B) semi-dry calcareous grasslands (clusters 5-7), C) dry calcareous grasslands (clusters 8-9), and D) dry siliceous grasslands (cluster 10). Frequencies of the diagnostic species in the ten clusters are summarized in Table 1.

The DCA diagram of Figure 4 shows the floristic relationships between these clusters. As gradient length of the first DCA axis was 6.24 standard deviation units, the use of an unimodal ordination is quite appropriate. The first DCA axis was positively correlated with slope and



rock cover, and negatively with plant cover. Dry calcareous grasslands were positioned in the positive part of this axis, while mesic grasslands were in the negative part. The second DCA axis showed a positive correlation with altitude and dry siliceous grasslands were positioned in its positive part. South and west components of aspect had a very low correlation with first and second DCA axes. According to the Monte Carlo permutation test, only rock cover, altitude and slope were significant in CCA as explanatory variables of the variation of species composition, corresponding to the former the stronger relationship.

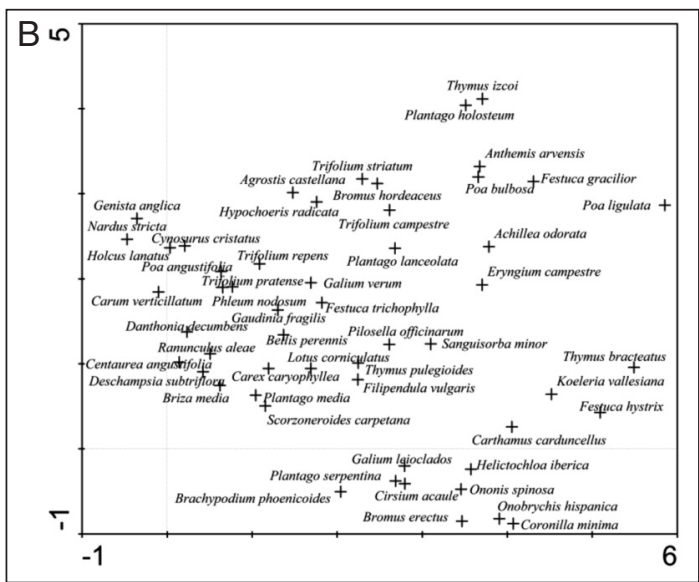

Figure 4. - DCA ordination plots obtained from the vegetation data. Axis 1 and 2 explains the $5.9 \%$ and the $4 \%$ of the total species variability, respectively. Sample-environment biplot (A) shows the distribution of sites according to the dendrogram clusters (cluster numbers are the same as in Table 1). Environmental variables are: altitude, slope, south component of exposure (S), west component of exposure (W), rock cover, plant cover, total cover of Iberian endemics (IbE_Cov), and species richness of Iberian endemics (IbE_R). Species plot (B) only includes the species with higher weights $(>15)$ along the gradients. 
Table 1

Synoptic table of the grasslands studied in the southwestern Iberian System. Columns correspond to the ten clusters obtained in the beta-flexible classification, ordered according to the four main groups. Frequency values of species in every group are shown. Dark grey shaded values indicate $\Phi$ values $\geq 50 \%$ and light grey shading values $50 \%>\Phi \geq 25 \%$.

\begin{tabular}{|c|c|c|c|c|c|c|c|c|c|c|}
\hline Higher level group & $\mathrm{A}$ & A & A & A & $\mathrm{B}$ & B & B & $\mathrm{C}$ & $\mathrm{C}$ & $\mathrm{D}$ \\
\hline Cluster No. & 1 & 2 & 3 & 4 & 5 & 6 & 7 & 8 & 9 & 10 \\
\hline N. of relevés & 19 & 6 & 16 & 25 & 26 & 11 & 6 & 26 & 5 & 20 \\
\hline N. order & 1 & 2 & 3 & 4 & 5 & 6 & 7 & 8 & 9 & 10 \\
\hline Lolium perenne & 63 & . & . & 16 & 4 & . & . & . & . & . \\
\hline Trifolium dubium & 58 & . & 31 & 12 & . & 9 & . & . & . & . \\
\hline Bromus hordeaceus & 74 & 33 & 6 & 4 & 4 & 27 & . & 8 & . & 40 \\
\hline Cares muricata subsp. pairae & 37 & 17 & . & 4 & . & . & . & . & . & . \\
\hline Phleum nodosum & 95 & 33 & 56 & 68 & 38 & 27 & 83 & . & . & 10 \\
\hline Convolvulus arvensis & 47 & 17 & . & 4 & 12 & . & 33 & 4 & . & . \\
\hline Trifolium striatum & 63 & 67 & . & 8 & 8 & . & 17 & 4 & . & 45 \\
\hline Poa angustifolia & 53 & . & 25 & 20 & 8 & 27 & 50 & . & . & . \\
\hline Trisetum flavescens & 37 & . & 19 & 4 & . & 9 & 33 & . & . & . \\
\hline Trifolium pratense & 63 & 17 & 62 & 52 & 8 & 55 & 33 & . & . & . \\
\hline Festuca trichophylla & 89 & 83 & 75 & 84 & 50 & 45 & 83 & . & . & 20 \\
\hline Trifolium campestre & 84 & 100 & 19 & 52 & 46 & 55 & 83 & 4 & . & 80 \\
\hline Jasione montana & . & 67 & . & . & . & . & . & . & . & 10 \\
\hline Agrostis castellana & 32 & 100 & 38 & 12 & . & 45 & . & 4 & . & . \\
\hline Jasione crispa subsp. sessiliflora & . & 50 & . & . & . & . & . & . & . & 10 \\
\hline Conopodium pyrenaeum & . & 50 & 12 & 4 & . & . & . & . & . & . \\
\hline Nardus stricta & 11 & . & 94 & . & . & 9 & . & . & . & . \\
\hline Genista anglica & 5 & 17 & 75 & . & . & . & . & . & . & 5 \\
\hline Anthoxanthum odoratum & . & . & 62 & 12 & . & . & . & . & . & . \\
\hline Juncus squarrosus & . & . & 44 & 4 & . & . & . & . & . & . \\
\hline Carex leporina & 5 & . & 38 & . & . & . & . & . & . & . \\
\hline Carex panicea & 5 & . & 38 & . & . & . & . & . & . & . \\
\hline Cerastium fontanum subsp. vulgare & . & . & 38 & 8 & . & . & . & . & . & . \\
\hline Potentilla erecta & . & . & 31 & . & . & . & . & . & . & . \\
\hline Stachys officinalis & . & . & 44 & 4 & . & 18 & . & . & . & . \\
\hline Geum hispidum & 11 & . & 38 & . & . & . & . & . & . & . \\
\hline Luzula campestris & 16 & 17 & 56 & 4 & 4 & 9 & . & . & . & 10 \\
\hline Euphrasia hirtella & 11 & 17 & 56 & 28 & . & 18 & . & . & . & . \\
\hline Danthonia decumbens & 5 & 33 & 62 & 40 & . & 27 & . & . & . & . \\
\hline Helictochloa marginata & . & . & 38 & . & 4 & . & . & . & . & 25 \\
\hline Orchis coriophora & 5 & 17 & 44 & 4 & . & . & 17 & . & . & 5 \\
\hline Rhinanthus minor & . & . & 31 & 12 & 4 & . & . & . & . & . \\
\hline Saxifraga granulata & 5 & . & 38 & 4 & . & 9 & . & . & . & 20 \\
\hline Holcus lanatus & 32 & 17 & 56 & 16 & . & 9 & 33 & . & . & . \\
\hline Scorzoneroides carpetana & 11 & . & 25 & 52 & 31 & 9 & . & . & . & . \\
\hline Centaurea jacea subsp. angustifolia & 16 & . & 44 & 56 & 4 & 27 & . & . & . & . \\
\hline Carex caryophyllea & . & 33 & 25 & 60 & 4 & 9 & 33 & . & . & 10 \\
\hline Leontodon hispidus & 11 & 33 & 19 & 44 & . & . & . & . & . & . \\
\hline Lotus corniculatus & 74 & 33 & 75 & 100 & 73 & 100 & 100 & 4 & . & 20 \\
\hline Prunella hyssopifolia & 5 & 17 & 12 & 44 & 15 & 27 & 33 & $\cdot$ & . & . \\
\hline Coronilla minima & . & . & . & . & 81 & 27 & 17 & 27 & 20 & 10 \\
\hline Jasonia tuberosa & . & . & $\cdot$ & . & 35 & . & . & . & . & . \\
\hline Polygala monspeliaca & 5 & . & . & . & 38 & . & 17 & . & . & $\dot{0}$ \\
\hline Carthamus carduncellus & . & 17 & 6 & 12 & 77 & 73 & . & 42 & . & 25 \\
\hline Hippocrepis comosa & . & . & . & . & 31 & 9 & . & 4 & . & . \\
\hline Onobrychis argentea subsp. hispanica & 11 & . & . & . & 50 & 36 & 17 & 12 & . & 5 \\
\hline
\end{tabular}




\begin{tabular}{|c|c|c|c|c|c|c|c|c|c|c|}
\hline N. order & 1 & 2 & 3 & 4 & 5 & 6 & 7 & 8 & 9 & 10 \\
\hline $\begin{array}{l}\text { Helianthemum oelandicum subsp. } \\
\text { incanum }\end{array}$ & . & . & . & . & 58 & 27 & 17 & 38 & 20 & 15 \\
\hline Ononis cristata & 5 & . & . & 4 & 46 & 36 & . & 12 & 20 & . \\
\hline Leucanthemum pallens & 5 & . & . & 4 & 31 & 27 & . & & . & \\
\hline Potentilla neumanniana & . & & . & . & 50 & 55 & 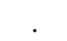 & 35 & 20 & 30 \\
\hline Medicago sativa & 21 & 17 & . & . & 38 & 27 & 17 & & 20 & \\
\hline Bromopsis erecta & 5 & & & & 42 & 91 & 17 & 15 & 20 & 5 \\
\hline Thymus pulegioides & 16 & 17 & 25 & 20 & 4 & 73 & 17 & . & . & 15 \\
\hline Trifolium ochroleucon & 11 & 33 & 19 & 12 & 12 & 64 & . & & . & 5 \\
\hline Salvia pratensis & . & . & . & 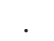 & 4 & 36 & & 12 & . & \\
\hline Geum sylvaticum & . & 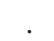 & 6 & & 23 & 55 & 17 & 8 & . & 25 \\
\hline Filipendula vulgaris & 5 & 50 & 56 & 56 & 23 & 82 & 33 & 4 & . & 20 \\
\hline Brachypodium phoenicoides & 5 & . & . & 8 & 4 & 45 & 100 & 4 & . & . \\
\hline Polygala calcarea & . & . & . & 8 & . & 18 & 50 & & . & \\
\hline Thymus bracteatus & . & . & . & . & 50 & 18 & $\cdot$ & 96 & . & 15 \\
\hline $\begin{array}{l}\text { Anthyllis vulneraria subsp. } \\
\text { vulnerarioides }\end{array}$ & es. & . & . & . & . & . & . & 54 & . & 5 \\
\hline Xeranthemum inapertum & 5 & . & . & . & 8 & . & . & 81 & 60 & 20 \\
\hline Androsace maxima & . & . & . & . & . & . & . & 62 & 40 &. \\
\hline Poa ligulata & . & . & . & . & . & . & . & 58 & 20 & 15 \\
\hline Arenaria obtusiflora subsp. ciliaris & 11 & . & . & & 4 & 9 & . & 46 & . & 10 \\
\hline Bromus squarrosus & 11 & . & & 12 & 4 & . & . & 58 & 40 & 5 \\
\hline Alyssum simplex & . & . & . & . & . & 9 & . & 46 & 20 & 10 \\
\hline Carduus assoi & . & . & . & . & 4 & . & . & 46 & 40 & . \\
\hline Teucrium chamaedrys & . & . & . & . & . & . & . & 31 & 20 & \\
\hline Marrubium supinum & . & . & . & . & 4 & & . & 35 & 20 & 10 \\
\hline $\begin{array}{l}\text { Dianthus pungens subsp. } \\
\text { brachyanthus }\end{array}$ & . & . & . & . & 4 & 9 & . & 46 & 40 & 20 \\
\hline Bombycilaena erecta & 11 & . & . & . & 12 & 9 & . & 54 & 80 & 5 \\
\hline Helianthemum apenninum & . & . & & & 27 & 18 & 17 & 54 & 40 & 15 \\
\hline Armeria alliacea subsp. matritensis & . & . & 6 & 16 & 4 & 27 & . & 42 & 20 & 5 \\
\hline Arenaria erinacea & . & . & . & . & . & . & . & 31 & 40 & . \\
\hline Crupina vulgaris & . & . & . & . & 4 & . & . & 31 & 40 & \\
\hline Convolvulus lineatus & . & . & . & . & 12 & . & 17 & 35 & 20 & 15 \\
\hline Asphodelus cerasiferus & . & . & . & . & 4 & . & . & 31 & 60 & 5 \\
\hline Artemisia pedemontana & . & . & . & . & . & . & . & 19 & 100 & . \\
\hline Sideritis hirsuta & . & . & . & . & 8 & . & . & 15 & 100 & \\
\hline Phlomis lychnitis & . & . & . & . & 4 & . & . & 4 & 80 & 5 \\
\hline Taeniatherum caput-medusae & . & . & . & . & . & . & . & 4 & 60 & \\
\hline Thymus vulgaris & . & . & & . & 35 & . & 17 & 8 & 80 & 5 \\
\hline Thymus zygis subsp. sylvestris & . & . & . & . & . & . & . & . & 40 & . \\
\hline Trigonella gladiata & . & . & . & . & . & . & . & . & 40 & . \\
\hline Centaurea paniculata subsp. castellana & . & . & & . & . & . & . & . & 40 & \\
\hline Thymus leptophyllus subsp. izcoi & . & 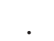 & . & . & . & . & . & . & . & 85 \\
\hline Plantago holosteum & 5 & 67 & 6 & . & 4 & . & . & 4 & . & 100 \\
\hline Scleranthus polycarpos & 5 & 33 & . & . & . & 9 & . & 4 & . & 80 \\
\hline Sedum amplexicaule & 16 & 67 & . & . & . & 9 & . & 12 & . & 95 \\
\hline Potentilla cinerea & 5 & 17 & . & . & . & . & . & . & . & 65 \\
\hline Evax carpetana & . & 50 & . & . & . & . & . & 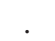 & . & 65 \\
\hline Festuca rivas-martinezii & & . & 6 & & . & & . & & . & 40 \\
\hline Cerastium pumilum & 21 & . & 6 & 4 & 8 & 9 & . & 31 & 20 & 70 \\
\hline Festuca glacilior & & & . & 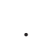 & 12 & & . & 12 & 40 & 55 \\
\hline Petrorhagia prolifera & 5 & 50 & . & 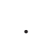 & 4 & 9 & . & 38 & 20 & 70 \\
\hline Koeleria crassipes & . & 17 & . & & . & 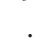 & . & & . & 35 \\
\hline
\end{tabular}




\begin{tabular}{|c|c|c|c|c|c|c|c|c|c|c|}
\hline N. order & 1 & 2 & 3 & 4 & 5 & 6 & 7 & 8 & 9 & 10 \\
\hline Herniaria cinerea & . & 17 & . & . & . & . & . & . & . & 35 \\
\hline Crucianella angustifolia & . & 17 & . & . & 4 & . & . & 23 & 20 & 50 \\
\hline Trifolium strictum & 16 & 17 & 6 & . & . & . & . & . & . & 40 \\
\hline Poa bulbosa & 47 & 17 & 6 & 12 & 12 & 9 & 17 & 38 & . & 70 \\
\hline Pilosella castellana & . & 50 & . & . & . & . & . & . & . & 40 \\
\hline Carduus carpetanus & 11 & 17 & . & . & . & . & . & 4 & . & 30 \\
\hline Achillea odorata & 21 & 33 & . & 16 & 62 & 82 & 33 & 50 & 20 & 85 \\
\hline Anthyllis vulneraria subsp. gandogeri & . & . & . & . & 8 & . & . & 8 & 40 & 35 \\
\hline Trifolium arvense & 5 & 33 & . & . & . & . & . & . & . & 30 \\
\hline Aira caryophyllea & 21 & 67 & 38 & 4 & . & 18 & . & . & . & 55 \\
\hline Ranunculus paludosus & 16 & 33 & 12 & 4 & 4 & 9 & . & . & . & 40 \\
\hline Anthemis arvensis & 26 & 33 & 6 & 4 & . & 9 & . & 31 & 20 & 50 \\
\hline Trifolium repens & 95 & 33 & 12 & 72 & 12 & 36 & 17 & . & . & 35 \\
\hline Cynosurus cristatus & 68 & . & 56 & 28 & . & 9 & . & . & . & . \\
\hline Bellis perennis & 79 & . & 44 & 68 & 23 & 9 & 33 & . & . & 5 \\
\hline Gaudinia fragilis & 42 & . & 6 & 36 & . & . & . & . & . & . \\
\hline Hypochaeris radicata & 74 & 100 & 50 & 44 & 12 & 18 & 17 & . & . & 35 \\
\hline Achillea tomentosa & . & 83 & . & . & . & . & . & 8 & . & 45 \\
\hline Rumex acetosella subsp. angiocarpus & 11 & 83 & 6 & . & . & . & . & . & . & 75 \\
\hline Logfia minima & 5 & 67 & . & . & . & . & . & . & . & 40 \\
\hline Carum verticillatum & 32 & . & 94 & 60 & . & . & 17 & . & . & . \\
\hline Ranunculus bulbosus subsp. aleae & 42 & . & 88 & 92 & 27 & 18 & 67 & . & . & . \\
\hline $\begin{array}{l}\text { Deschampsia caespitosa subsp. } \\
\text { subtriflora }\end{array}$ & 32 & . & 75 & 100 & 15 & 27 & 33 & . & . & . \\
\hline Plantago media & 37 & . & 69 & 96 & 23 & 91 & 67 & . & . & . \\
\hline Plantago maritima subsp. serpentina & 5 & . & . & 60 & 69 & 18 & . & . & . & . \\
\hline Briza media & 5 & . & 56 & 72 & 4 & 73 & 17 & . & . & . \\
\hline Festuca hystrix & . & . & . & . & 81 & 27 & . & 96 & 60 & 5 \\
\hline Koeleria vallesiana & 11 & . & . & 4 & 100 & 64 & 50 & 100 & 100 & 45 \\
\hline Galium estebanii var. leioclados & 16 & . & 50 & 20 & 77 & 82 & 83 & 4 & . & 10 \\
\hline Helictochloa pratensis subsp. iberica & . & . & . & 8 & 58 & 73 & 50 & 15 & 40 & 15 \\
\hline Cirsium acaule & 16 & . & 25 & 36 & 62 & 100 & 50 & 8 & . & 5 \\
\hline
\end{tabular}

Next, a brief description of the vegetation types inferred from the classification, their diagnostic species and the related syntaxa is given (see also the syntaxonomical scheme included after the section of Discussion).

Group A is very heterogeneous and comprises wet meadows and mesic grasslands growing on well-developed soils, usually, at the bottom of valleys and with a $100 \%$ plant cover. Cluster 1 includes the southern Oroiberian intensively grazed grasslands of Phleo nodosi-Cynosuretum cristati (RodRÍGUEZ-ROJO \& FERNÁNDEZ GONZÁLEZ, 2014) characterized by Lolium perenne, Trifolium dubium, Bromus hordeaceus, Phleum nodosum, Trisetum flavescens, Trifolium striatum, T. campestre, etc. Cluster 2 includes grasslands growing on siliceous soils moderately wet in spring and characterized by Agrostis castellana, Jasione montana and J. crispa subsp. sessiliflora. Cluster 3 corresponds to Nardus stricta swards with Genista anglica (Genisto anglicae-Nardetum strictae) that grow in deep, siliceous and hydromorphic soils, characterized by a high number of diagnostic species such as Genista anglica, Nardus stricta, Anthoxanthum odoratum, Juncus squarrosus, Potentilla erecta, Luzula campestris, Carex leporina, etc. Finally, cluster 4 includes pastures growing on temporarily wet, base-rich and clayey soils, characterized by Deschampsia cespitosa subsp. subtriflora, Leontodon hispidus, Scorzoneroides carpetana, Carex caryophyllea, Centaurea jacea, Prunella hyssopifolia, etc, and framed into the Sanguisorbo lateriflorae-Deschampsietum refractae. Although the presence of Trifolium repens and Bellis perennis indicates floristic similarities with Cynosurus cristatus grasslands, as 
well as, intensive grazing, Sanguisorbo-Deschampsietum is also characterized by Plantago media and P. maritima subsp. serpentina, indicators of the calcareous nature of soils.

Group B represents the typical semi-dry calcareous grasslands of the region (Festuco-Brometea). Cluster 6 includes the Oroiberian calcareous grasslands adscribed to Cirsio microcephalaeOnobrychidetum hispanicae characterized by Bromopsis erecta, Thymus pulegioides, Trifolium ochroleucon, Salvia pratensis, etc; while cluster 7 is related to the Brachypodium phoenicoides communities growing in valley bottoms at lower altitudes, which should be framed into the Maestracensean Festuco andresmolinae-Brachypodietum phoenicoidis. Cluster 5 represents a transition between the semi-dry grasslands (Cirsio-Onobrychidetum hispanicae) and the dry pastures from cryoturbated soils (Festucetum hystricis) (Figure 4). Diagnostic species of this cluster are Coronilla minima, Jasonia tuberosa, Carthamus carduncellus, Polygala monspeliaca, Onobrychis argentea subsp. hispanica, Ononis cristata, etc.; among the diagnostic species shared with Cirsio-Onobrychidetum are Cirsium acaule, Helictochloa pratensis subsp. iberica and Galium estebanii var. leioclados. Festuca hystrix and Thymus bracteatus denote the xerophytic character of this type of grasslands and its relationship with cluster 8. Plantago maritima subsp. serpentina is characteristic of clayey or loamy soils, lightly humid and basic to saline (PEDROL, 2009), and it denotes the typical substrates associated to these grasslands. The slope arrow in the DCA diagram points towards this cluster, and the ANOVA test showed significant differences in slope with respect to cluster 6 (semi-dry grasslands) but not to cluster 8 (dry grasslands) (Figure 5).

Group C contains the most typical Oroiberian short and sparse grasslands proper to upfrozen soils and framed into the Sideritido fontquerianae-Arenarion microphyllae. Cluster 8 corresponds to the Festucetum hystricis, characterized by Thymus bracteatus, Anthyllis vulneraria subsp. vulnerarioides, Poa ligulata, Carduus assoi, Dianthus pungens subsp. brachyanthus, Armeria alliacea subsp. matritensis, etc. Cluster 9 corresponds to the Paronychio capitatae-Artemisietum lanatae, mainly characterized by Arte-


Figure 5. - Box-and-whisker plot of altitude, slope and rock cover in the ten clusters obtained in the beta-flexible classification (cluster numbers are the same as in Table 1 and text). Post hoc comparisons were tested with ANOVA (Tukey for altitude and Kruskal-Wallis by ranks for rock cover and slope; $\mathrm{p}$ values considered for significance are $<0.05$ ).

misia pedemontana. The arrow corresponding to rock cover points towards these two clusters in the DCA diagram (Figure 4). According to the ANOVA test, rock cover is significantly higher in 
these two clusters, excepting for cluster 5 (transitional to semi-dry grasslands) (Figure 5). The xerophytic character of this group is reflected by the high number of annuals among its diagnostic species (Xeranthemum inapertum, Androsace maxima, Alyssum simplex, Bombycilaena erecta, etc). Richness in Iberian endemics is also correlated with rock cover (Figure 4). The endemic diagnostic species for group $\mathrm{C}$ are Arenaria erinacea, Arenaria obtusiflora subsp. ciliaris, Armeria alliacea subsp. matritensis, Carduus assoi, Centaurea paniculata subsp. castellana and Thymus bracteatus. Altitude is significantly higher in Festucetum hystricis than in ParonychioArtemisietum lanatae (Figure 5).

Group D only includes the xerophile thymegrasslands from siliceous bedrock soils (slates, sandstones and quartzites). Their floristic combination is characterized by the diagnostic species Thymus leptophyllus subsp. izcoi, Festuca rivasmartinezii, Plantago holosteum, Pilosella castellana and Koeleria crassipes, besides Rumex acetosella subsp. angiocarpus and several silicicolous therophytes (Aira caryophyllea, Evax carpetana, Scleranthus polycarpos, Logfia minima, etc). The high cover of Iberian endemics is due to the abundance of the Oroiberian Thymus leptophyllus subsp. izcoi and the Iberian Festuca rivas-martinezii. This vegetation type has been recently described (Fumano procumbentis-Thymetum izcoi G. Navarro; RodRíGUEZ-RoJo \& al., 2012).

\section{SPECIES RICHNESS}

Trends in species richness along the major floristic gradients are not linear. The GAM model shows skewed unimodal trends along the two DCA axes, the decrease in species richness being more evident along the first axis (Fig. 6). Species density ranges from a minimum value of 15 species per $100 \mathrm{~m}^{2}$, that corresponds to the clusters 5 and 9 , and a maximum of 51 , that corresponds also to the cluster 9 . The average of the species density ranges from 25 to 35 species, and the values around 30 (28-32) are the most frequent. The higher values appear around the center of the DCA diagram and are not associated to any particular cluster. Lower species richness values are

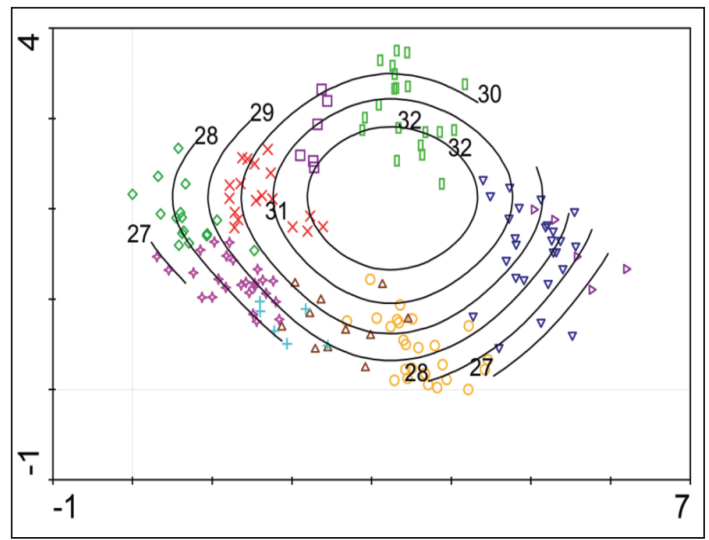

Figure 6. - Change in species richness along the first two DCA axes expressed as an attribute plot based on the GAM model (Poisson distribution, see legend in Figure 4).

associated to both extremes of the first DCA axis, corresponding to the Nardus stricta swards in the negative extreme, and the most xerophytic grasslands in the positive extreme. On the contrary, the number of Iberian endemics increases towards the positive part of the first DCA axis where calcareous dry grasslands are positioned (cluster 8). The cumulative number of Iberian endemics for this vegetation type is equal to 19 in total (see list of Iberian endemics in Appendix 1).

\section{DISCUSSION}

Topography and lithology are the main factors influencing the vegetation diversity of grasslands in the study area. Rock cover and slope are associated to a gradient of water availability that determine the major floristic differences: the wet and mesic meadows (Molinio-Arrhenatheretea and Nardetea) are positioned in flat terrains at the valley bottoms with null rock cover, while the dry grasslands (Festuco-Ononidetea and Festucetea indigestae) show the higher values for both variables. Floristic differences linked to lithological variability (calcareous vs. siliceous substrates) were larger in dry grasslands than in mesic grasslands. Siliceous thyme-grasslands of the Fumano-Thymetum izcoi appear well differentiated against calcareous dry grasslands by a large pool of diagnostic species from Festucetea indigestae and Tuberarie- 
talia. The lithological gradient is narrower in the mesic grasslands, opposing the associations PhleoCynosuretum cristati (cluster 1), from more or less decalcified soils, to Sanguisorbo-Deschampsietum hispanicae (cluster 4) from base-rich soils. However, more analysis would be needed involving other environmental variables, such as soil properties or grazing intensity, for the interpretation of the community diversity of mesic meadows.

Differences in altitude appeared among communities belonging to the same major vegetation types. For instance, although the two types of semi-dry grasslands (Festuco-Brometea) were characterized by few diagnostic species and their clusters were linked at the lowest dissimilarity level in the dendrogram, they showed altitudinal differences: $\mathrm{Cir}$ sio-Onobrychidetum hispanicae occurs at higher altitudes, in the upper suprasubmediterranean belt (altitudes: 1300-1600 m) whereas Festuco-Brachypodietum phoenicoidis at lower altitudes (altitudes: $1100-1500 \mathrm{~m}$ ). However, only a community analysis of the Festuco-Brometea grasslands in all the southern Iberian System with more phytosociological data would bring out a right ecological interpretation of the environmental patterns in this grassland type. It is also interesting the relation between siliceous thyme-grasslands and altitude in the DCA diagram, although altitude is not significantly higher compared with the rest of the grassland groups. These thyme-grasslands have a wide altitudinal range, reaching the highest belts of the mountains crowned by Paleozoic quartzites (Sierra de Albarracín, Sierra Menara and Sierra de Valdemeca), above $1800 \mathrm{~m}$.

The classification results were explained according to the flexible beta method selected, but the performance of the three applied clustering methods allowed us to compare differences in the linkage of some intermediate vegetation types, as it is the case of the semi-dry grasslands (group B) with moisture requirements intermediate between mesic and dry grasslands. Moreover, in combination with the ordination analysis, it is possible to reinterpret the similarity level between clusters separated in the dendrogram. For instance, cluster 5 was linked in the Ward dendrogram to the cluster node of the typical dry calcareous grasslands (Sideritido-Arenarion). But in the divisive TWINSPAN method, cluster 5 showed more affinity with the typical semidry grasslands (Cirsio-Onobrychidetum), and even their respective centroids were much closer in the DCA scatter plot where the two groups do not appear well separated. Cluster 5 has been treated here as a transitional community between Cirsio-Onobrychidetum and Festucetum hystricis and its syntaxonomical position cannot be clarified only upon the cluster dendrogram, but also upon the diagnostic species analysis and the information of the topographic variables. Onobrychis argentea subsp. hispanica, Ononis cristata, Leucanthemum pallens, Medicago sativa and Cirsium acaule may lead to interpret this type of vegetation as belonging to the CirsioOnobrychidetum hispanicae, but Festuca hystrix and Thymus bracteatus are also diagnostic and are even more abundant (cover values from 20 to $40 \%$ ). On the other hand, the ANOVA test for the rock cover and slope variables showed that cluster 5 does not differ from cluster 8 (Festucetum hystricis) while it does from cluster 6 (Cirsio-Onobrychidetum). RIvAs-GODAY \& BORJA (1961) described in Sierra de Gúdar (eastern Iberian System), a submediterranean subassociation for Cirsio-Onobrychidetum characterized by Koeleria vallesiana, Carthamus carduncellus and Linum salsoloides, that would be the most frequent subassociation in our study territory. Cirsio-Onobrychidetum is limited to shady places in closed valleys, at the bottoms or hillsides, usually under the canopy of Pinus sylvestris forests (LóPEZ GonZÁLEZ, 1978), where the warm temperatures of summer are attenuated. In open exposed situations, in deforested valleys and steep sites, the grasslands become more xerophytic, and if the grazing intensity is high, as it usually occurs in the surroundings of rural villages, xericity is more stressed as a consequence of the effect of the erosion of the superficial soil with the bedrock coming to the surface. Only dry grasslands may colonize these exposed and topographic sites that are related to the Festucetum hystricis. However, in clay and loamy soils, a variant in transition to semidry grasslands may occur with the presence of Jasonia tuberosa, Plantago maritima subsp. serpentina, Cirsium acaule, Helictochloa pratensis subsp. iberica and Galium estebanii var. leioclados, and cluster 5 represents this vegetation type (Table 2). The presence of Jasonia tuberosa 


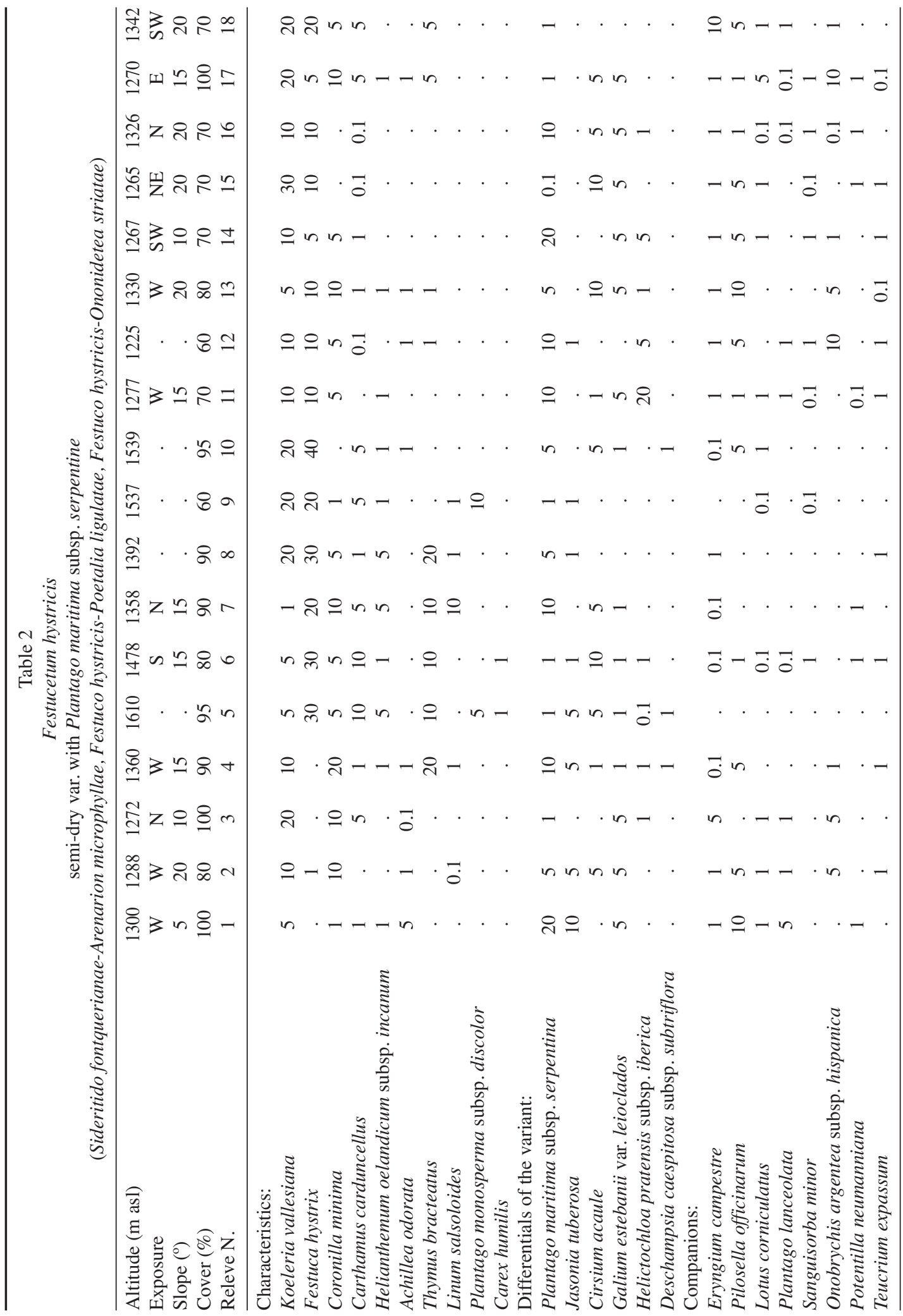




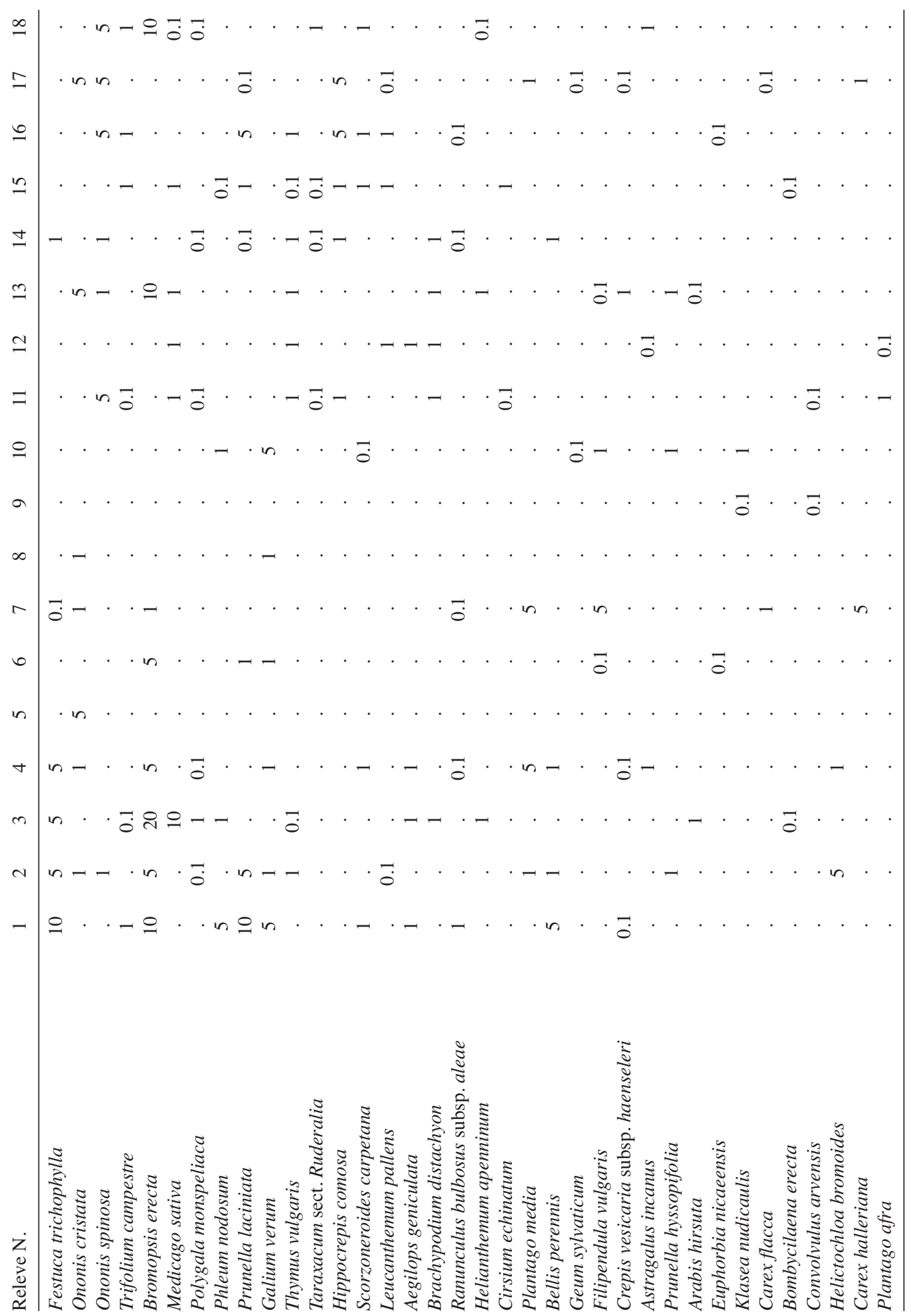




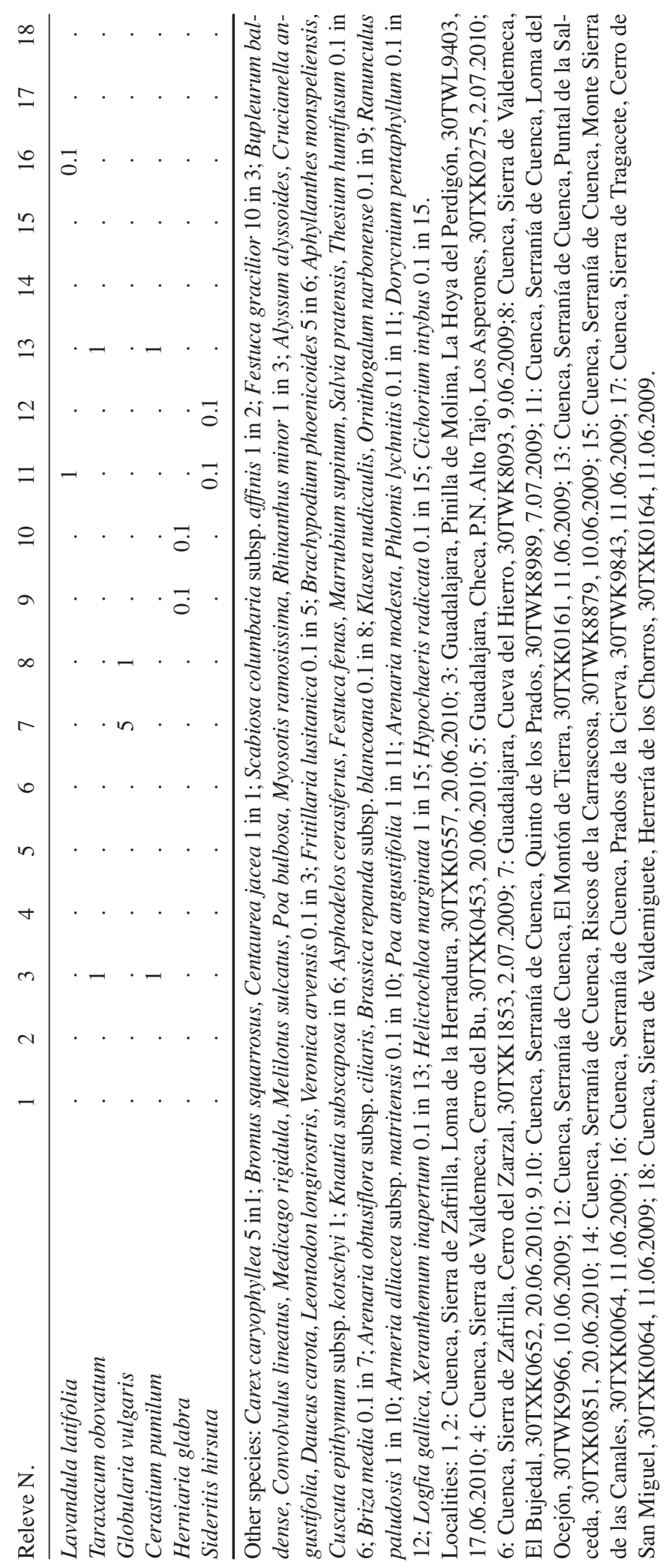


and Plantago maritima subsp. serpentina in this community also denotes a similarity with the most xerophilous grasslands of the Deschampsion mediae (Plantagini serpentinae-Jasonietum tuberosae O. Bolós \& Masalles in O. Bolós 1983; Prunello hyssopifoliae-Plantaginetum serpentinae Biurrun 1999; Eryngio dilatati-Jasonietum tuberosae Torres \& Cano 2000) (Torres \& al., 2000). On the other hand, although Jasonia tuberosa is not present in our samples from the Sanguisorbo-Deschampsietum grasslands, LÓPEZ-GONZÁLEZ (1978) did include it in his table of the association. The ecological factor that is associated to this floristical similarity is explained by some edaphic and lithological affinities: compact and base-rich, clayed soils.

The number of species recorded in the mountain grasslands of the southwestern Iberian System is analogous to that referred in previous studies in the Western European mountains (KOPEĆ \& al., 2010). The DCA diagram showed that an increase in species richness is not skewed towards any of the vegetation types. According to our results, the grassland communities recorded do not differ significantly in species richness at the spatial grain of $100 \mathrm{~m}^{2}$. At first, it was expected that it was higher in the temperate semi-dry calcareous grasslands (Cirsio-Onobrychidetum hispanicae), reported as one of the plant communities with the world record for plant species richness (WILSON \& al., 2012), but the submediterranean context of the Iberian System is far from the optimum of these temperate grasslands in central Europe. If species richness in grasslands from more hydromorphic soils is reduced by competitive exclusion of the high abundances of few species, and is also reduced in more xerophytic grasslands by hydric stress, then mesic or semi-dry grasslands would contain more species richness. This tendency may be interpreted in the species richness plot based on the fitted additive model (Fig. 6). On the other hand, the negative effect of soil acidification on plant species richness observed by previous authors (PÄRTEL, 2002; PIQUERAY \& al., 2007; KoPeĆ \& al., 2010) is not evident in the southern Oroiberian grasslands, maybe as a consequence of the Mediterranean character of the siliceous thyme-grasslands that are locally rich in annual species.

As a conclusion, the evaluation of the floristic value of the semi-natural grasslands in the southwestern Iberian System should take into account other criteria such as the endangered status, the level of rarity and the endemicity of the species composition. According to the latter, the Sideritido fontquerianae-Arenarion microphyllae grasslands, included in the Annex I of Habitats Directive, represent one of the most valuable vegetation types of this area.

\section{ACKNOWLEDGEMENTS}

This research was carried out with the financial aid of the University of Castilla-La Mancha Research Program during 2009-2010 (TC20091114), and the Global Change, Earth Sciences and Biodiversity Program of the Spanish Ministry of Education and Science (CGL2009-13317-C03-03, project SIVIM).

\section{SYNTAXONOMICAL SCHEME OF THE GRASSLANDS IN THE SOUTHWESTERN IBERIAN SYSTEM (SYNTAXONOMY NOMENCLATURE FOLLOWS RIVAS-MARTÍNEZ, 2011)}

MoLINIO-ARRHENATHERETEA Tüxen 1937

Arrhenatheretalia elatioris Tüxen 1931

Cynosurion cristati Tüxen 1947

Phleo nodosi-Cynosuretum cristati Rodríguez-Rojo \& Fernández-González 2014 in press

Holoschoenetalia vulgaris Br.-Bl. ex Tchou 1948

Deschampsion mediae Br.-B1. in Br.-B1., Roussine \& Nègre 1952

Sanguisorbo lateriflorae-Deschampsietum hispanicae Rivas-Martínez \& G. López in G. López 1978 corr. Rivas-Martínez, Fernández-González, Sánchez-Mata \& Pizarro 1990 
FestuCo-BRometeA Br.-Bl. \& Tüxen ex Klika \& Hadăc 1944

Brometalia erecti Br.-Bl. 1936

Teucrio pyrenaici-Bromion erecti Rivas-Martínez, Fernández-González \& Loidi 1999

Cirsio microcephalae-Onobrychidetum hispanicae Rivas Goday \& Borja 1961 corr. Rivas-Martínez, Fernández-González \& Loidi 1999

Brachypodietalia phoenicoidis Br.-B1. ex Molinier 1934

Brachypodion phoenicoidis Br.-B1. ex Molinier 1934

Festuco andresmolinae-Brachypodietum phoenicoidis Rivas Goday \& Borja 1961 corr. RivasMartínez, T.E. Díaz, Fernández-González, Izco, Loidi, Lousã \& Penas 2002

Festuco hystricis-ononidetea striatae Rivas-Martínez, T.E. Díaz, F. Prieto, Loidi \& Penas 2002

Festuco hystricis-Poetalia ligulatae Rivas Goday \& Rivas-Martínez 1963

Sideritido fontquerianae-Arenarion microphyllae Rivas-Goday \& Borja 1961 corr. Rivas-Martínez, T.E. Díaz, Fernández-González, Izco, Loidi, Lousã \& Penas 2002

Festucetum hystricis Font Quer 1954

typicum

variant semi-dry with Plantago maritima subsp. serpentina

Paronychio capitatae-Artemisietum assoanae Rivas Goday \& Borja 1961 corr. Rivas-Martínez 2011

FESTUCETEA INDIGESTAE Rivas Goday \& Rivas-Martínez 1971

Jasiono sessiliflorae-Koelerietalia crassipedis Rivas-Martínez \& Cantó 1987

Hieracio castellani-Plantaginion radicatae Rivas-Martínez \& Cantó 1987

Fumano procumbentis-Thymetum izcoi G. Navarro ex Rodríguez-Rojo \& al. 2012

\section{REFERENCES}

Amezaga, I., Mendarte, S., Albizu, I., Besga, G., Garbisu, C. \& Onaindia, M. -2004- Grazing intensity, aspect, and slope effects on limestone grassland structure Rangel. Ecol. Manag. 57(6): 606-612.

Barrera, I. - 1985- Contribución al estudio de la flora y de la vegetación de la Sierra de Albarracín. Memoria doctoral. Facultad de Biología. Universidad Complutense de Madrid. 499 pp.

Bennie, J., Hill, M.O., Baxter, R. \& Huntley, B. -2006Influence of slope and aspect on long-term vegetation change in British chalk grasslands - J. Ecol. 94: 355368.

Botta-Dukát, Z., Chytrý, M., Hájková, P. \& Havlová, M. 2005 - Vegetation of lowland wet meadows along a climatic continentality gradient in central Europe - Preslia 77: $89-111$

Castroviejo, S. (coord.). 1986-2012. Flora iberica 1-8, 1015, 17-18, 21. R. Jard. Bot., CSIC, Madrid.

Critchley, C.N.R., Chambers, B. J., Fowbert, J.A., Sanderson, R.A., Bhogal, A. \& Rose, S.C. -2002- Association between lowland grassland plant communities and soil properties - Biol. Conserv. 105: 199-215.

Ewald, J. -2003 - The calcareous riddle: why are there so many calciphilous species in the Central European flora? - Folia Geobot. 38: 357-366.

Gavilán, R.G., Díez-Monsalve, E., Izquierdo, J.L., Gutiérrez-Girón, A., Fernández-González, F. \& SánchezMata, D. - 2012- An approach towards the knowledge of
Iberian high-mountain calcareous grasslands - Lazaroa 33: 43-50

Gutiérrez Elorza, M. \& Peña Monné, J.L. -1994- Cordillera Ibérica - In: Gutiérrez Elorza, M. (coord..). Geomorfología de España. Pp. 251-286. Ed. Rueda, Madrid.

Jiménez-Alfaro, B., Marceno, C., Bueno, A., Gavilán, R. \& Obeso, J.R. - 2013- Biogeographic deconstruction of alpine plant communities along altitudinal and topographic gradients - J. Veg. Sci. doi: 10.1111/jvs.12060

Klimek, S., Richter gen. Kemmermann, A., Hofmann, M. \& Isselstein, J. -2007- Plant species richness and composition in managed grasslands: the relative importance of field management and environmental factors Biol. Conserv. 134: 559-570.

Kopeć, M., Zarzycki, J. \& Gondek, K. -2010 - Species diversity of submontane grasslands: effect of topographic and soil factors - Pol. J. Ecol. 58(2): 285-295.

López González, G. -1978- Contribución al conocimiento fitosociológico de la Serranía de Cuenca, II. An. Inst. Bot. Cav. 34(2): 597-702.

Marini, L., Scotton, M., Klimek, S., Isselstein, J. \& Pecile, A. - 2007- Effects of local factors on plant species richness and composition of Alpine meadows - Agric. Ecosys. Env. 119: 281-288.

Maurer, K., Weyand, A., Fischer, M. \& Stöcklin, J. 2006- Old cultural traditions, in addition to land use and topography, are shaping plant diversity of grasslands in the Alps - Biol. Conserv. 130: 438-446. 
McCune, B. \& Mefford, JB. -1999- PC-ORD. Multivariate Analysis of Ecological Data. Version 5.0. MjM Software, Gleneden Beach, OR.

Moeslund, J.E., Arge, L., Bøcher, P.K., Dalgaard, T., Ejrnæs, R., Odgaard, M.Y. \& Svening, J.-C. - 2013 - Topographically controlled soil moisture drives plant diversity patterns within grasslands - Biodiv. Conserv. 22(10): 2151-2166.

Pärtel, M. - 2002 - Local plant diversity patterns and evolutionary history at the regional scale - Ecology 83(9): 2361-2366.

Pedrol, J. -2009 - Plantago L. - In: Benedí, C., Rico, E., Güemes, J. \& Herrero, A. (Eds.). Flora iberica 13. Pp. 438. R. Jard. Bot., CSIC, Madrid.

Piqueray, J., Bisteau, E., Bottin, G. \& Mahy, G. -2007Plant communities and species richness of the calcareous grasslands in southeast Belgium - Belg. J. Bot. 140(2): 157-173.

Rivas-Goday, S. \& Borja, J. -1961 - Estudio de la vegetación y flórula del macizo de Gúdar y Jabalambre An. Inst. Bot. Cavanilles 19: 1-550.

Rivas-Martínez, S. -2007- Mapa de series, geoseries y permaseries de vegetación de España (Mapa de vegetación potencial de España). Parte I. - Itinera Geobot. 17: 5-436.

Rivas-Martínez, S. -2011 - Mapa de series, geoseries y geopermaseries de vegetación de España [Memoria del Mapa de Vegetación Potencial de España] Parte 2. - Itinera Geobot. 18(2): 5-424.

Rodríguez-Rojo, M.P. \& Fernández-González, F. -2014Diversity patterns and typology of Cynosurus cristatus grasslands (Cynosurion cristati Tüxen 1947) in the Iberian Peninsula. - Folia Geobot. (in press).

Rodríguez-Rojo, M.P., Madrigal, J., Crespo, G. \& Fernández-González, F. -2010 - Tipología de los prados y pastizales calcícolas de la Serranía de Cuenca (Sistema Ibérico) - In: Calleja, A., García Navarro, R., Ruiz Mantecón, A. \& Peláez Suárez, R. (Eds.). Pastos:
Fuente Natural de Energía. Pp. 15-21. Ed. Univ. León, León..

Rodríguez-Rojo, M.P., Madrigal, J., Sardinero, S., Bouso, V. \& Fernández-González, F. - 2011 - Diversidad fitocenótica y especies indicadores de los pastos herbáceos del Sistema Ibérico en Castilla-La Mancha - In: LópezCarrasco, C., Rodríguez-Rojo, M.P., San Miguel Ayanz, A., Fernández-González, F. \& Roig, S. (Eds.). Pastos, paisajes culturales entre tradición y nuevos paradigmas del siglo XXI. Pp. 155-160. S.E.E.P.

Rodríguez-Rojo, M.P., Crespo, G., Madrigal, J. \& Fernández-González, F. -2012 - Contribution to the knowledge of some rare plant communities from the southwestern Iberian System - Lazaroa 33: 27-42.

Roleček J., Tichý L., Zelený D. \& Chytrý M. -2009- Modified TWINSPAN classification in which the hierarchy respects cluster heterogeneity - J. Veg. Sci. 20: 596602.

ter Braak, C.J.F. \& Šmilauer, P. - 2002- CANOCO reference manual and CanoDraw for Windows user's guide: Software for canonical community ordination. Ver. 4.5. Microcomputer Power. Ithaca. 500 pp.

Tichý, L. - 2002- JUICE, software for vegetation classification. - J. Veg. Sci. 13: 451-453.

Tichý, L. \& Chytrý, M. - 2006- Statistical determination of diagnostic species for site groups of unequal size J. Veg. Science 17: 809-818.

Torre, J.A., García-Fuentes, A., Salazar, C., Melendo, M. \& Cano, E. - 2000 - Contribuciones al conocimiento de la alianza Deschampsion mediae Br.-B1. in Br.-Bl. et al. 1952 en las sierras subbéticas del sur de la Península Ibérica. Acta Bot. Malacitana 25: 219-227.

Van der Maarel, E. - 1979- Transformation of coverabundance values in phytosociology and its effects on community similarity. - Vegetatio 39: 97-114.

Wilson, J.B., Peet, R.K., Dengler, J. \& Pärtel, M. - 2012 Plant species richness: the world records. - J. Veg. Sci. 23: 796-802.

Received: 1 July 2013

Accepted: 3 December 2013 
APPENDIX 1

Iberian endemics present in the ten vegetation clusters (numbers correspond to the synoptic table).

\begin{tabular}{|c|c|c|c|c|c|c|c|c|c|c|}
\hline Cluster number & 1 & 2 & 3 & 4 & 5 & 6 & 7 & 8 & 9 & 10 \\
\hline Arenaria erinacea & & & & & & & & $*$ & $*$ & \\
\hline Arenaria obtusiflora subsp. ciliaris & $*$ & & & & $*$ & $*$ & & $*$ & & * \\
\hline Armeria alliacea subsp. matritensis & & & $*$ & $*$ & $*$ & $*$ & & $*$ & $*$ & $*$ \\
\hline Biscutella atropurpurea & & & & & & & & & & $*$ \\
\hline Brassica repanda subsp. blancoana & & & & & $*$ & & & & & \\
\hline Carduus assoi & & & & & $*$ & & & $*$ & $*$ & \\
\hline Centaurea cavanillesiana & & & & & & & & $*$ & & \\
\hline Centaurea paniculata subsp. castellana & & & & & & & & & $*$ & \\
\hline Centaurea pinae & & & & & & & & $*$ & & $*$ \\
\hline Dianthus legionensis & & $*$ & & & & & & & & \\
\hline Euphorbia minuta & & & & $*$ & & & $*$ & $*$ & & \\
\hline Festuca marginata subsp. andres-molinae & & & & & & $*$ & & & & \\
\hline Festuca paniculata subsp. paui & & & & & & & & $*$ & & \\
\hline Festuca rivas-martinezii & & & $*$ & & & & & & & $*$ \\
\hline Galium lucidum subsp. fruticescens & & & & & & & $*$ & $*$ & & \\
\hline Jasione crispa subsp. sessiliflora & & * & & & & & & & & $*$ \\
\hline Knautia subscaposa & & $*$ & & & $*$ & $*$ & $*$ & $*$ & & \\
\hline Leucanthemopsis pallida var. virescens & & & & & & & & $*$ & & $*$ \\
\hline Linum salsoloides & & & & & $*$ & $*$ & & $*$ & & $*$ \\
\hline Minuartia campestris & & & & & & & & $*$ & & \\
\hline Plantago monosperma subsp. discolor & & & & & $*$ & & & $*$ & & * \\
\hline Sanguisorba lateriflora & $*$ & $*$ & & $*$ & * & & * & & & \\
\hline Satureja intricata subsp. gracilis & & & & & & & & & $*$ & \\
\hline Scorzoneroides carpetana & $*$ & & $*$ & $*$ & $*$ & $*$ & & & & \\
\hline Sedum nevadense & $*$ & & & & & & & & & \\
\hline Senecio minutus & & & & & & & & $*$ & & \\
\hline Seseli cantabricum & & & $*$ & & & & & & & \\
\hline Silene legionensis & & & & & & $*$ & & $*$ & $*$ & $*$ \\
\hline Silene mellifera & & & & & & $*$ & & & & \\
\hline Tanacetum vahlii & & & & & & & & & & $*$ \\
\hline Teucrium expassum & & & & & $*$ & $*$ & & $*$ & $*$ & $*$ \\
\hline Thymelaea pubescens & & & & & & & & $*$ & & \\
\hline Thymus bracteatus & & & & & $*$ & $*$ & & $*$ & & $*$ \\
\hline Thymus leptophyllus subsp. izcoi & & & & & & & & & & $*$ \\
\hline
\end{tabular}

